Article

\title{
Thermo-Responsive Graphene Oxide/Poly(Ethyl Ethylene Phosphate) Nanocomposite via Ring Opening Polymerization
}

\author{
Xue Jiang ${ }^{1,2}\left(\right.$, Guolin $\mathrm{Lu}^{2}$, Xiaoyu Huang ${ }^{2, *}, \mathrm{Yu} \mathrm{Li}^{1}{ }^{1}$, Fangqi Cao ${ }^{1}$, Hong Chen ${ }^{1}$ and \\ Wenbin Liu ${ }^{1, *}$ \\ 1 Shanghai Key Laboratory of Crime Scene Evidence, Shanghai Research Institute of Criminal Science and \\ Technology, Zhongshan North No 1 Road, Shanghai 200083, China; 13795305289@163.com (X.J.); \\ 13675113399@163.com (Y.L.); frankie-cao@163.com (F.C.); chenhong2898@163.com (H.C.) \\ 2 Key Laboratory of Synthetic and Self-Assembly Chemistry for Organic Functional Molecules, Shanghai \\ Institute of Organic Chemistry, Chinese Academy of Sciences, 345 Lingling Road, Shanghai 200032, China; \\ luguolin@mail.sioc.ac.cn \\ * Correspondence: wbliu1981@163.com (W.L.); xyhuang@sioc.ac.cn (X.H.); Tel.: +86-21-22028361 (W.L.); \\ +86-21-54925310 (X.H.)
}

Received: 28 December 2018; Accepted: 29 January 2019; Published: 5 February 2019

\begin{abstract}
An efficient strategy for growing thermo-sensitive polymers from the surface of exfoliated graphene oxide (GO) is reported in this article. GO sheets with hydroxyls and epoxy groups on the surface were first prepared by modified Hummer's method. Epoxy groups on GO sheets can be easily modified through ring-opening reactions, involving nucleophilic attack by tris(hydroxymethyl) aminomethane (TRIS). The resulting GO-TRIS sheets became a more versatile precursor for next ring opening polymerization (ROP) of ethyl ethylene phosphate (EEP), leading to GO-TRIS / poly(ethyl ethylene phosphate) (GO-TRIS-PEEP) nanocomposite. The nanocomposite was characterized by ${ }^{1} \mathrm{H}$ NMR, Fourier transform infrared spectroscopy (FT-IR), X-ray photoelectron spectroscopy (XPS), thermogravimetric analysis (TGA), differential thermal gravity (DTG), transmission electron microscopy (TEM) and atomic force microscopy (AFM). Since hydrophilic PEEP chains make the composite separate into single layers through hydrogen bonding interaction, the dispersity of the functionalized GO sheets in water is significantly improved. Meanwhile, the aqueous dispersion of GO-TRIS-PEEP nanocomposite shows reversible temperature switching self-assembly and disassembly behavior. Such a smart graphene oxide-based hybrid material is promising for applications in the biomedical field.
\end{abstract}

Keywords: graphene oxide; PEEP; ROP; grafting-from

\section{Introduction}

Graphene oxide (GO), a single layer of carbon atoms in a closely packed honeycomb two-dimensional lattice with carboxylic acid, epoxide, and hydroxyl groups, has attracted considerable attention in recent years [1-9]. GO, which is highly hydrophilic, can be prepared using cheap graphite as raw material by cost-effective chemical methods with a high yield. The biocompatibility of GO renders it a good candidate for application in the biomedical field [10-13]. The presence of abundant functional groups at the surface of GO may be very interesting since that they provide enough reactive sites for the subsequent chemical modification using known carbon surface chemistry [14]. Recently, a considerable number of works have been performed on enhancing the properties of GO by adding additional functionality to the groups already present on the surface of GO [15-28]. In particular, "intelligentizing" graphene can been obtained by attaching stimuli-responsive polymers 
to the backbone of GO [21-28]. These attachments are typically made by either grafting-from or -onto approaches. The vast majority of the triggers reported so far are confined to temperature [21-24], $\mathrm{pH}[24,25]$, light $[26,27]$ and redox [28].

Polyphosphoesters (PPEs) are known to be a class of biocompatible polymers with repeated phosphoester attachments in the backbone [29-33]. As the phosphorus atom has multivalent property, the physicochemical properties can be easily modified by means of introduction into such polymers with different functional groups. According to the type of side groups connected to the phosphorous atom, PPEs are classified as polyphosphate, polyphosphonate, polyphosphite or polyphosphoramidate [33]. Among them, polyphosphates are an important family of PPEs, which have attracted great attention for biological and phamaceutical applications such as drug release, gene transfer, and tissue engineering [34-37]. Under usual physiological conditions, polyphosphates can readily degrade through hydrolysis or enzymatic cleavage of the phosphoester bonds. In addition to the excellent biocompatibility and biodegradability, it has been demonstrated that polyphosphates also exhibit thermo-responsibility in aqueous solution so as to make them possess great potential as novel smart biomaterials [32,38]. However, no one has reported on a PPE-based GO/polymer nanocomposite until now.

Herein, we have successfully designed and prepared a kind of PPE-based temperature- responsive $\mathrm{GO} /$ polymer nanocomposite (Scheme 1), in which a typical hydrophilic polyphosphoester, i.e., poly(ethyl ethylene phosphate) (PEEP), was covalently connected on the surface of GO by ring opening polymerization (ROP) of ethyl ethylene phosphate (EEP) initiated by the hydroxyls on GO surface introduced by tris(hydroxymethyl) aminomethane (TRIS). The obtained GO-TRIS-PEEP nanocomposite has robust temperature-responsive properties resulting from a change in the PEEP conformation on GO surface. When raising the temperature, PEEP chains may become hydrophobic and collapse so that the nanocomposite precipitated from the solution. Owing to the excellent biocompatibility, biodegradability and thermo-responsibility of PEEP chains, the prepared nanocomposite shows a bright prospect in the field of smart nanocarrier for controlled release under temperature stimuli.
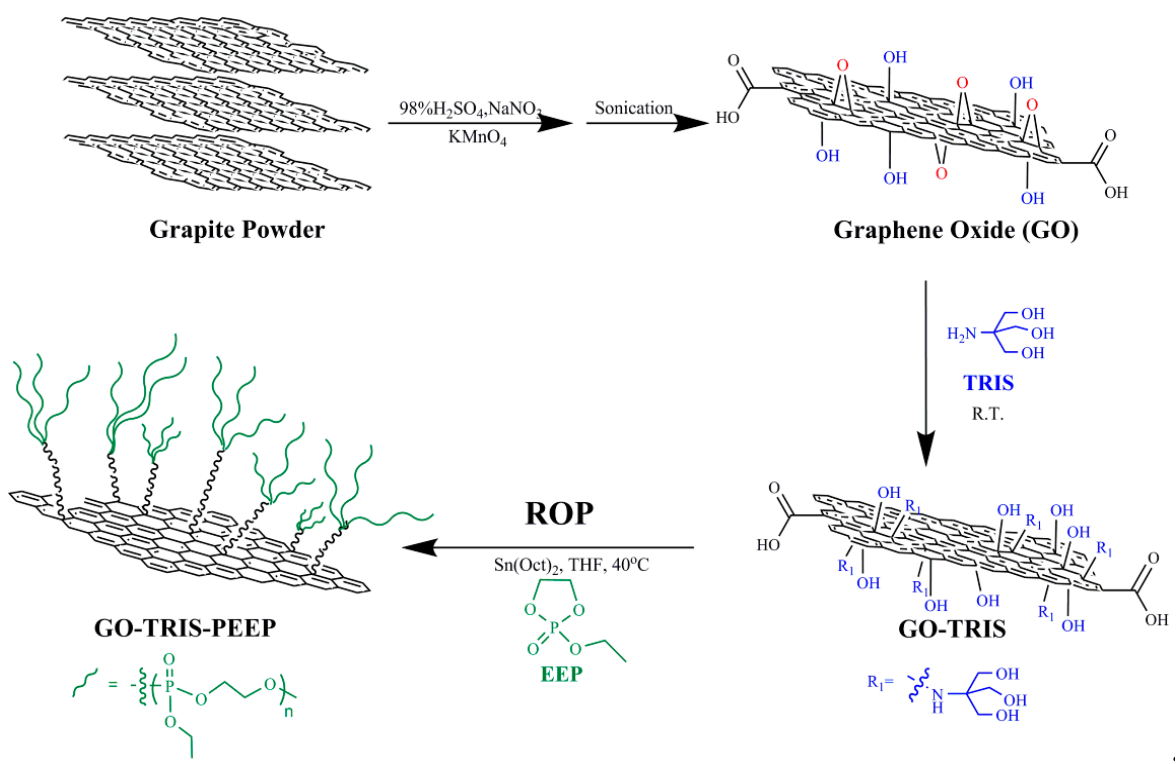

Scheme 1. Preparation of graphene oxide-tris(hydroxymethyl) aminomethane-poly(ethyl ethylene phosphate) (GO-TRIS-PEEP) nanocomposite. 


\section{Experimental}

\subsection{Characterization}

${ }^{1} \mathrm{H}$ NMR measurements were performed on a JEOL resonance ECZ $400 \mathrm{~S}(400 \mathrm{MHz})$ spectrophotometer (Tokyo, Japan) in $\mathrm{CDCl}_{3}$ or $\mathrm{D}_{2} \mathrm{O}$, TMS was used as internal standard. Fourier transform infrared (FT-IR) spectra were recorded on a Nicolet AVATAR-360 FT-IR spectrophotometer (Waltham, MA, USA) with a resolution of $4 \mathrm{~cm}^{-1}$. Elemental analysis was carried out on a Carlo-Erba 1108 system (Milan, Italy). X-ray photoelectron spectroscopy (XPS) was recorded on a Perkin Elmer PHI 5000c ESCA photoelectron spectrometer (Waltham, IN, USA). Thermogravimetric analysis (TGA) was carried out with a TA Q500 thermal analyzer (New Castle, IN, USA) from $50{ }^{\circ} \mathrm{C}$ to $600{ }^{\circ} \mathrm{C}$ at a heating rate of $10^{\circ} \mathrm{C} / \mathrm{min}$ in $\mathrm{N}_{2}$. Transmission electron microscopy (TEM) images were obtained by a JEOL JEM 1230 instrument (Tokyo, Japan) operated at $80 \mathrm{kV}$. Atomic force microscopy (AFM) images were taken by a Veeco DI MultiMode SPM (Plainview, TX, USA) in the tapping mode of dropping the sample solution onto the freshly exfoliated mica substrate. Differential scanning calorimetry (DSC) measurement was run on a TA Q200 (New Castle, IN, USA) system under $\mathrm{N}_{2}$ purge with a heating rate of $10^{\circ} \mathrm{C} \mathrm{min}^{-1}$.

\subsection{Preparation of GO Sheets}

Exfoliated GO sheets were prepared by a modified Hummer's method using graphite powder as starting material. Graphite powder (99.99+\%, Aldrich) was firstly oxidized by sulfuric acid $\left(\mathrm{H}_{2} \mathrm{SO}_{4}\right.$, Aldrich, $95-98 \%)$ and potassium permanganate $\left(\mathrm{KMnO}_{4}\right.$, Aldrich, $\left.99 \%\right)$ followed by filtration and subsequent dialysis or by several runs of centrifugation/washing to completely remove residual salts and acids. Finally, graphite oxide dispersion $\left(0.1 \mathrm{mg} \mathrm{mL}^{-1}\right)$ was exfoliated by waterbath ultrasonication for $3 \mathrm{~h}$. GO sheets were recovered by filtration and vacuum drying.

\subsection{Preparation of TRIS-Bonded Graphene Sheets (GO-TRIS)}

GO (2.3 g) was treated with $12.2 \mathrm{~g}$ of 1,1,1-tris(hydroxymethyl) methanamine (TRIS, Aldrich, 99\%) in $500 \mathrm{~mL}$ of anhydrous $\mathrm{N}, \mathrm{N}$-dimethylformamide (DMF, Aldrich, $99.8 \%$ ) at room temperature for $36 \mathrm{~h}$ to transform the epoxy groups on the basal plane of GO into hydroxyls. The crude product was filtered through a $0.22 \mu \mathrm{m}$ filter and washed exhaustively with deionized water. The obtained GO-TRIS (2.4 g) was dried overnight at $40^{\circ} \mathrm{C}$ in vacuo.

\subsection{Preparation of Ethyl Ethylene Phosphate (EEP)}

Tetrahydrofuran (THF, Aldrich, 99\%) was dried over $\mathrm{CaH}_{2}$ and distilled from sodium and benzophenone under $\mathrm{N}_{2}$ prior to use. Triethylamine $\left(\mathrm{Et}_{3} \mathrm{~N}\right.$, Aldrich, $\left.99.5 \%\right)$ was dried over $\mathrm{KOH}$ and distilled over $\mathrm{CaH}_{2}$ under $\mathrm{N}_{2}$ prior to use. A mixture of ethanol (EtOH, Aldrich, 99.8\%, $8.8 \mathrm{~mL}, 0.15 \mathrm{~mol})$ and $\mathrm{Et}_{3} \mathrm{~N}(20.9 \mathrm{~mL}, 0.15 \mathrm{~mol})$ was added dropwise to a solution of 2-chloro-1,3,2dioxaphospholane-2-oxide (COP, Aldrich, 90\%-94\%, $21.4 \mathrm{~g}$, $0.15 \mathrm{~mol})$ in anhydrous THF (250 mL) at $-5{ }^{\circ} \mathrm{C}$. The reaction mixture was stirred at $-5{ }^{\circ} \mathrm{C}$ for $30 \mathrm{~min}$ and then at room temperature for additional $12 \mathrm{~h}$. The resulting mixture was firstly filtered to remove the insoluble salt. The filtrate was concentrated and distilled under reduced pressure $\left(107 \mathrm{~Pa} / 95 \sim 97^{\circ} \mathrm{C}\right)$ to give $15.5 \mathrm{~g}$ of yellowish liquid, ethyl ethylene phosphate (EEP), with a yield of $68 \% .{ }^{1} \mathrm{H} \mathrm{NMR}\left(400 \mathrm{MHz}, \mathrm{CDCl}_{3}\right): \delta(\mathrm{ppm})$ : $1.38\left(3 \mathrm{H}, \mathrm{POCH}_{2} \mathrm{CH}_{3}\right), 4.22\left(2 \mathrm{H}, \mathrm{POCH}_{2} \mathrm{CH}_{3}\right), 4.42\left(4 \mathrm{H}, \mathrm{OCH}_{2} \mathrm{CH}_{2}\right)$.

\subsection{Preparation of PEEP-Grafted Graphene Sheets (GO-TRIS-PEEP)}

Tin-2-ethylhexanoate $\left(\mathrm{Sn}(\mathrm{Oct})_{2}\right.$, Aldrich, $98 \%$ ) was purified by distilling under reduced pressure $\left(20 \sim 40 \mathrm{~Pa} / 152{ }^{\circ} \mathrm{C}\right)$ after co-boiling with $p$-xylene twice prior to use [39]. A $25 \mathrm{~mL}$ Schlenk flask was first dried by sonication in acetone. It was then immersed in the diethyl ether solution of trimethylchlorosilane ( $5 \% \mathrm{TMSCl}$ ) overnight to remove the hydroxyls on the surface of glass. GO-TRIS 
(235 mg) was firstly added to the flask (flame-dried under vacuum prior to use) sealed with a rubber septum for degassing and kept under Ar. After three cycles of evacuation purging with purified Ar, anhydrous THF ( $15 \mathrm{~mL})$ and DMF $(2 \mathrm{~mL})$ were added via a gastight syringe followed by water-bath ultra-sonication for 30 minutes. The flask was then degassed by three cycles of freezing-pumping-thawing after EEP $(1.98 \mathrm{~g}, 13 \mathrm{mmol})$ was added. THF solution $(0.9 \mathrm{~mL})$ of $\mathrm{Sn}(\mathrm{Oct})_{2}(0.18 \mathrm{mmol})$ was added via a gastight syringe. The flask was again degassed by three cycles of freezing-pumping-thawing, followed by immersing the flask into an oil bath set at $40{ }^{\circ} \mathrm{C}$. The polymerization lasted $24 \mathrm{~h}$ and it was terminated by adding excess acetic acid. The crude product was filtered through a $0.22 \mu \mathrm{m}$ filter followed by washing with THF and deionized water. The precipitate was dried in vacuo at $45^{\circ} \mathrm{C}$ for $48 \mathrm{~h}$ to give the desired product of GO-TRIS-PEEP (156 mg). XPS (molecular molar ratio): C, 65.66\%; N, 0.98\%; O, 30.44\%, P, $1.89 \% .{ }^{1} \mathrm{H}$ NMR $\left(400 \mathrm{MHz}, \mathrm{D}_{2} \mathrm{O}\right): \delta$ (ppm): $1.12\left(3 \mathrm{H}, \mathrm{POCH}_{2} \mathrm{CH}_{3}\right), 3.81\left(2 \mathrm{H}, \mathrm{POCH}_{2} \mathrm{CH}_{3}\right), 4.16\left(4 \mathrm{H}, \mathrm{OCH}_{2} \mathrm{CH}_{2}\right)$. FT-IR: $v\left(\mathrm{~cm}^{-1}\right): 1727,1590$, $1226,1030,977,800,640,518$.

\section{Results and discussion}

\subsection{Preparation of GO-TRIS-PEEP}

The fabrication process of GO-TRIS-PEEP polymer-modified nanocomposite via ring opening polymerization of EEP monomer is outlined in Scheme 1. Commercial graphite powder was first oxidized to $\mathrm{GO}$ with the help of $\mathrm{KMnO}_{4}$ under strong acidic environment using the modified Hummer's method [40], as a result, new epoxy and hydroxyl functionalities were introduced to the surface of a graphene oxide sheet. The structure of the obtained GO was confirmed by FT-IR (Figure S1), XRD (Figure S2) and elementary analysis (Table S1). The obtained epoxy groups can be easily modified through ring-opening reactions, on the basis of the mechanism of nucleophilic attack by amine groups [17]. 1,1,1-Tris(hydroxymethyl) methanamine (TRIS) is a kind of primary amine with three hydroxyls, which has been extensively used in chemical modification of macroporous materials [41,42]. In this work, TRIS is required to improve the opportunity of grafting from the plane of GO sheet, rendering GO a more versatile precursor for a wide range of applications. XPS measurement was used to confirm the introduction of TRIS moiety. XPS spectrum of GO-TRIS shown in Figure 1 exhibits a significant nitrogen peak around the binding energy of $400 \mathrm{eV}$, which is absent in that of GO (Figure S3). Zooming in further revealed that the N1s band appeared at $402.2 \mathrm{eV}$ accompanied with a lower binding energy shoulder located at $399.8 \mathrm{eV}$, which is consistent with a previous report [43]. The appearance of N1s band suggested the successful covalent functionalization of TRIS units onto the surface of modified GO sheets; i.e., the formation of TRIS-modified GO (GO-TRIS). Moreover, Figure 1 also displays the elemental analysis result of GO-TRIS, which indicated that the nitrogen content $(\mathrm{N} \%)$ increased from 0 to $1.40 \%$ after the functionalization with TRIS. The $\mathrm{C} / \mathrm{N}$ ratio was estimated to be 38 $=(46.18 \mathrm{wt} \% / 12) /(1.40 \mathrm{wt} \% / 14)$ (1 TRIS group per 6.3 aromatic rings $)$, which agreed with the value (45) derived from XPS measurement. Additionally, the dispersity of GO-TRIS kept as good as GO in water or polar organic solvents as shown in the inset of Figure 1. The yellow color of GO sheets remained after the incorporation of TRIS moieties, which also suggested that GO-TRIS retained the oxygen-containing groups so as to stabilize the corresponding aqueous solution.

Thermo-responsive PEEP chains then grew from the fabricated hydroxyls on the surface through ROP. To ensure that there was no polymer chains adsorbed on the surface of GO, the obtained product was filtered through a $0.22 \mu \mathrm{m}$ filter followed by washing with THF constantly, until the P content determined by elementary analysis was detected to be zero in the filtrate. ${ }^{1} \mathrm{H}$ NMR and FT-IR analyses were employed to characterize the obtained product after ROP of EEP monomer for confirming GO functionalization and the presence of PEEP chains on the surface of GO. ${ }^{1} \mathrm{H}$ NMR spectrum of the resulting GO-TRIS-PEEP in $\mathrm{D}_{2} \mathrm{O}$ is shown in Figure 2A and the peaks located at $1.12(3 \mathrm{H})$ and 3.81 $(2 \mathrm{H}) \mathrm{ppm}$ are attributed to the $\mathrm{POCH}_{2} \mathrm{CH}_{3}$ moiety in the side group of PEEP, respectively. On the other hand, the proton resonance signal of $\mathrm{OCH}_{2} \mathrm{CH}_{2}$ moiety in the backbone of PEEP is also seen 
at $4.16 \mathrm{ppm}$. Owing to the existence of the hydrophilic PEEP chains, GO-TRIS-PEEP might be well dispersed in $\mathrm{D}_{2} \mathrm{O}$. GO-TRIS-PEEP showed relative strong bands at $3217,1726,1577$ and $1037 \mathrm{~cm}^{-1}$ in FT-IR spectrum (Figure 2B), corresponding to stretching vibrations of $\mathrm{O}-\mathrm{H}, \mathrm{C}=\mathrm{O}, \mathrm{C}=\mathrm{C}$ and $\mathrm{C}-\mathrm{O}$ groups, respectively. The stretching vibration peaks attributed to $\mathrm{P}=\mathrm{O}$ and $\mathrm{P}-\mathrm{O}-\mathrm{C}$ appear at 1226 and $977 \mathrm{~cm}^{-1}$ after ROP. These characteristic peaks are originated from polyphosphoester chains attached to the surface through ROP. These data clearly illustrate the successful ROP of EEP initiated by GO-TRIS.

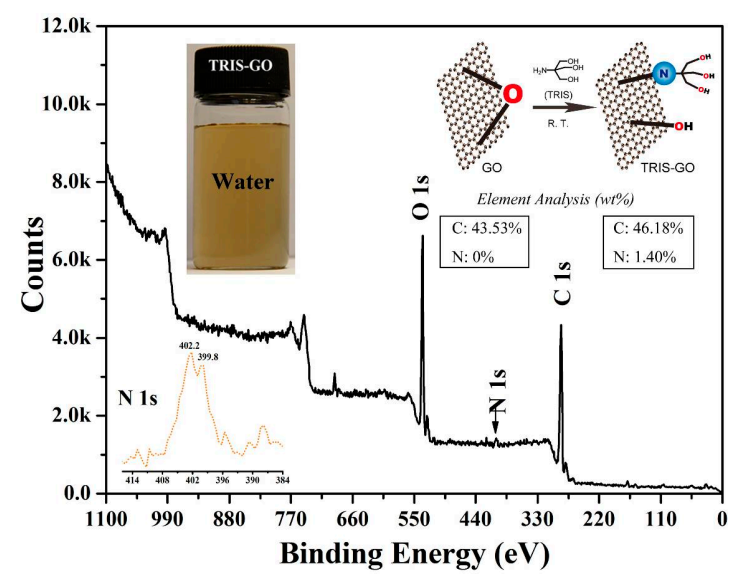

Figure 1. Survey X-ray photoelectron spectroscopy (XPS) data for GO-TRIS and photograph of well-dispersed GO-TRIS solution in water (inset).
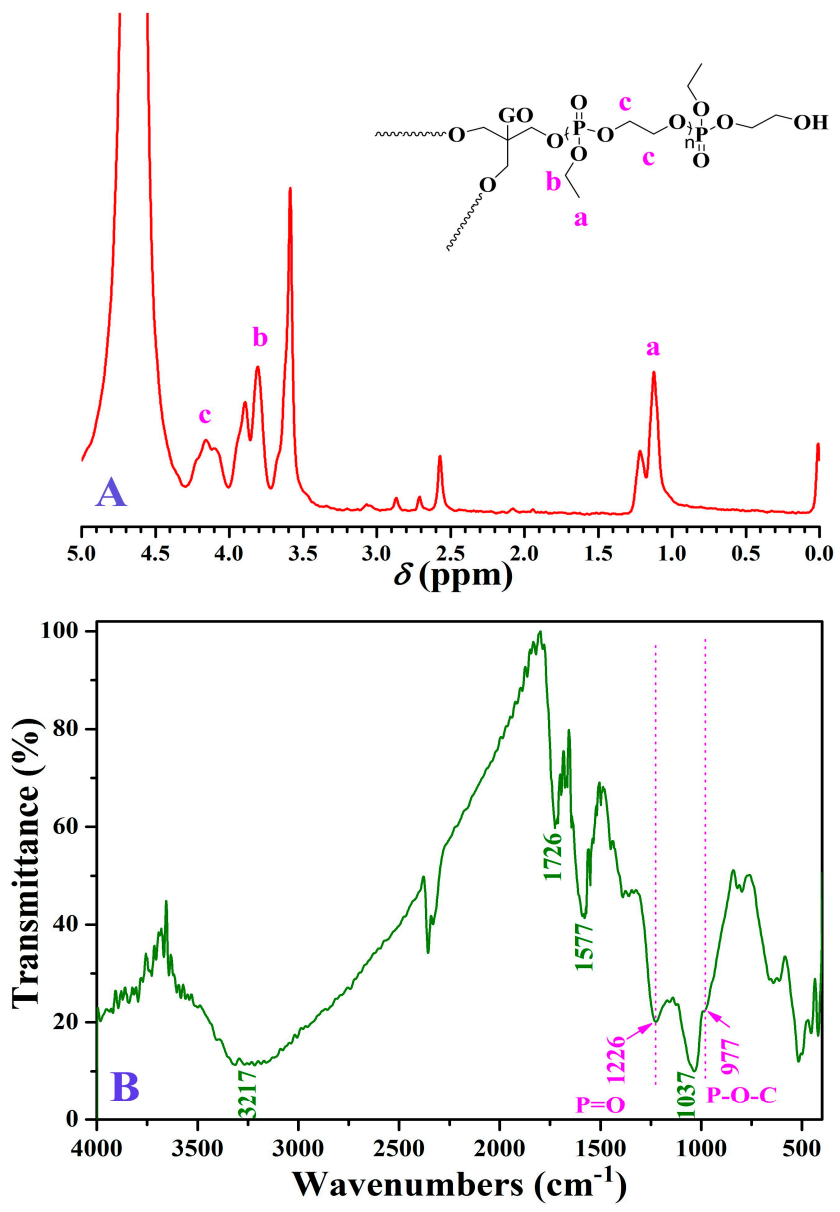

Figure 2. ${ }^{1} \mathrm{H}$ NMR (A) and Fourier transform infrared (FT-IR) (B) spectra of GO-TRIS-PEEP. 
To further understand the effective functionalization of PEEP chains on GO sheets, XPS measurement was employed to provide qualitative analysis. GO-TRIS-PEEP shows a strong peak of $\mathrm{C} 1 \mathrm{~s}$ at a binding energy around $285 \mathrm{eV}$, a weak peak of N1s at around $401.0 \mathrm{eV}$ and a peak at around $533 \mathrm{eV}$ originating from O1s (Figure 3). Furthermore, a peak at around $134 \mathrm{eV}$ is assigned to P2p3, which is resulted from PEEP chains. As the coordination between $\mathrm{Sn}$ of the catalyst and hydroxyls in the polymer chains [44], we also can observe the peaks of Sn4d around $24 \mathrm{eV}, \mathrm{SnO} 2$ around $487 \mathrm{eV}$ and Sn3d around $497 \mathrm{eV}$. The molar contents of C, O, N and P are 65.66\%, 30.44\%, 0.98\% and 1.89\%, respectively. The weight percentage of grafted PEEP in GO-TRIS-PEEP is estimated to be $21.5 \mathrm{wt} \%$ from Equation (1).

$$
\mathrm{PEEP} \%=\left[c_{\mathrm{P}} \times A_{\mathrm{P}} / \sum\left(c_{\mathrm{i}} \times A_{\mathrm{i}}\right)\right] \times(152 / 31) \times 100 \%
$$

TGA analysis of GO-TRIS-PEEP was performed to elucidate its thermal behavior and chemical composition. In comparison with the initial GO (Figure S4), the thermograph of the obtained GO-TRIS-PEEP (Figure 4) exhibits three major stages of decomposition in the temperature range of 50-600 ${ }^{\circ} \mathrm{C}$. The first stage shows a low weight loss until $125^{\circ} \mathrm{C}$, corresponding to the loss of adsorbed water into its structure. The second stage from $125^{\circ} \mathrm{C}$ to $250{ }^{\circ} \mathrm{C}$ can be assigned to the decomposition of oxygen-containing functionalities by evaporation of $\mathrm{CO}$ and $\mathrm{CO}_{2}$. The last weight loss occurs between $250{ }^{\circ} \mathrm{C}$ and $450{ }^{\circ} \mathrm{C}$, indicating the degradation of PEEP segment. To further investigate the enhancement of thermal properties, differential thermal gravity (DTG) curve of GO-TRIS-PEEP is also plotted in Figure 4. The peaks in DTG curve correspond to the temperatures at maximum rate of weight loss $\left(T_{\max }\right)$, and the outcome is entirely consistent with the TGA data. The quantity of PEEP chains attached to the surface of GO sheets is also determined from TGA. Figure 4 shows a $14.6 \mathrm{wt} \%(=79.6 \mathrm{wt} \%-65.0 \mathrm{wt} \%)$ weight loss at the temperature range from $250{ }^{\circ} \mathrm{C}$ to $450{ }^{\circ} \mathrm{C}$, and thus, the amount of PEEP chains grafted onto GO sheets is about $14.6 \mathrm{wt} \%$. Compared to GO, most of PEEP chains were exposed on the surface of GO-TRIS-PEEP, the measured phosphorus content by XPS might be higher than actual data. As a result, the XPS data $(21.5 \%)$ is a little higher than that obtained from TGA $(14.6 \%)$.

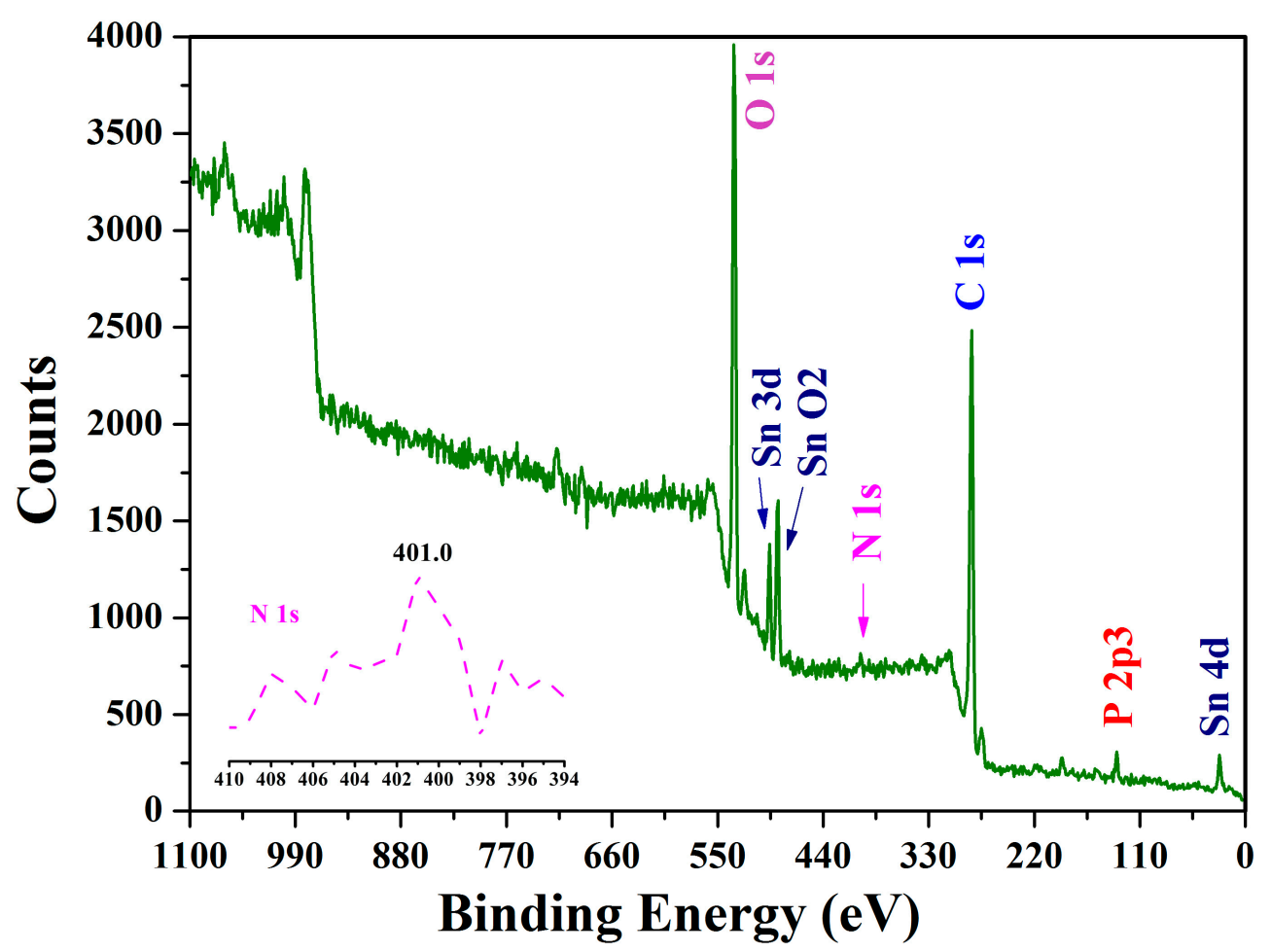

Figure 3. Survey XPS data for GO-TRIS-PEEP. 


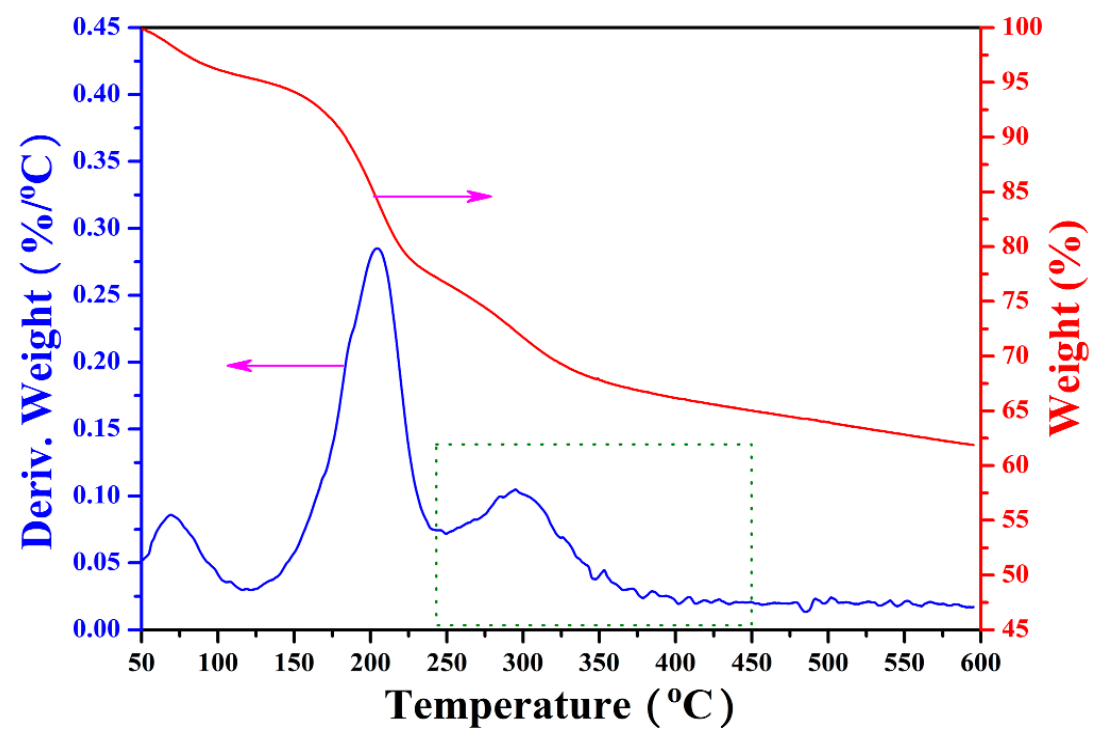

Figure 4. Thermogravimetric analysis (TGA)(red line) and differential thermal gravity (DTG) (blue line) curves of GO-TRIS-PEEP in $\mathrm{N}_{2}$.

\subsection{Surface Morphologies of GO-TRIS-PEEP Sheets}

A TEM micrograph of the fabricated GO-TRIS-PEEP is presented in Figure 5. It can be observed that the lamellar morphology of GO is preserved after ROP of EEP monomer, and the individual sheets have sizes of about $1 \mu \mathrm{m}$. Compared to GO (Figure S5), new dark dots appear because of the tangled mess formed by the grafted PEEP chains. Previous studies on GO have identified that carboxyls are at the periphery of sheets, while the oxygen-containing functionalities such as hydroxyl and epoxy group are on the basal plane $[45,46]$. As hydroxyls were used as initiating sites to trigger the polymerization of EEP monomer via surface-initiated ROP, the blackish polymeric chains spread evenly on the surface of the GO sheets, which is consistent with previous reports $[47,48]$. The grafted polymeric chains also destroyed the ordered $\pi-\pi$ stacking of graphitic basal planes so that functionalized GO sheets appeared to have better dispersion and exfoliation in methanol solution (Figure S6).

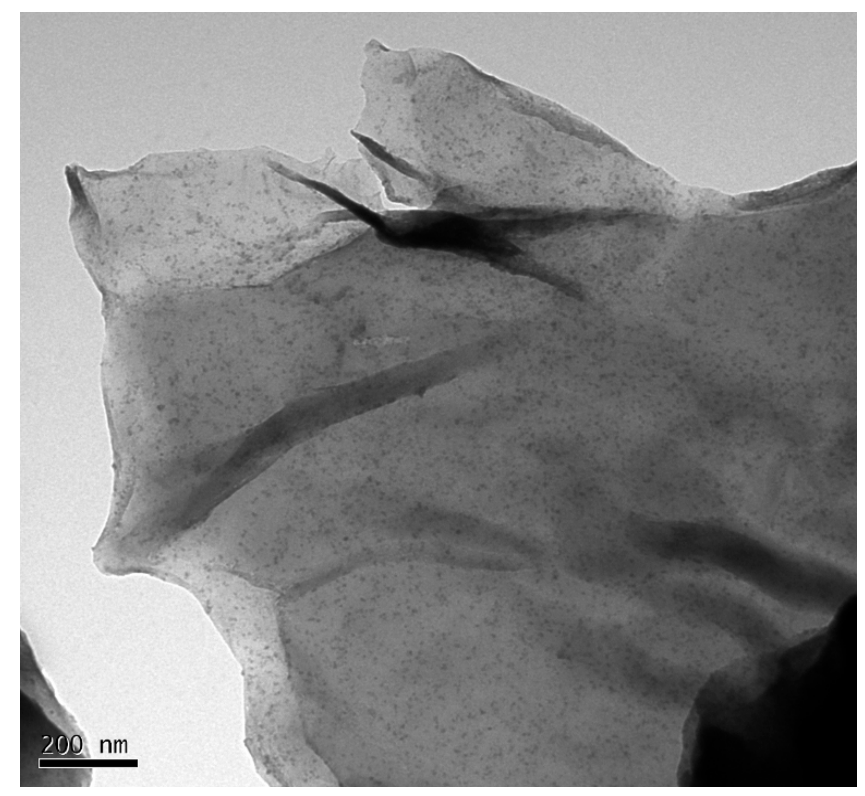

Figure 5. Transmission electron microscope (TEM) image of GO-TRIS-PEEP aqueous solutions with a concentration of $0.01 \mathrm{mg} / \mathrm{mL}$ using drop-casting method. 
AFM provides a direct method to characterize the surface morphology and thickness of GO-TRIS-PEEP sheets. As shown in Figure 6, GO-TRIS-PEEP sheets have an average in-plane size with several hundreds of nanometers. The surfaces of GO-TRIS-PEEP sheets are very rough compared to those of pristine GO sheets (Figure S7) and the thickness of GO-TRIS-PEEP sheets is measured to be approximately $10 \mathrm{~nm}$ from the average height profiles, which is much higher than that of pristine GO sheets. Both the rough surfaces and higher thickness of GO-TRIS-PEEP sheets further demonstrate the successful polymeric grafting [49-51].

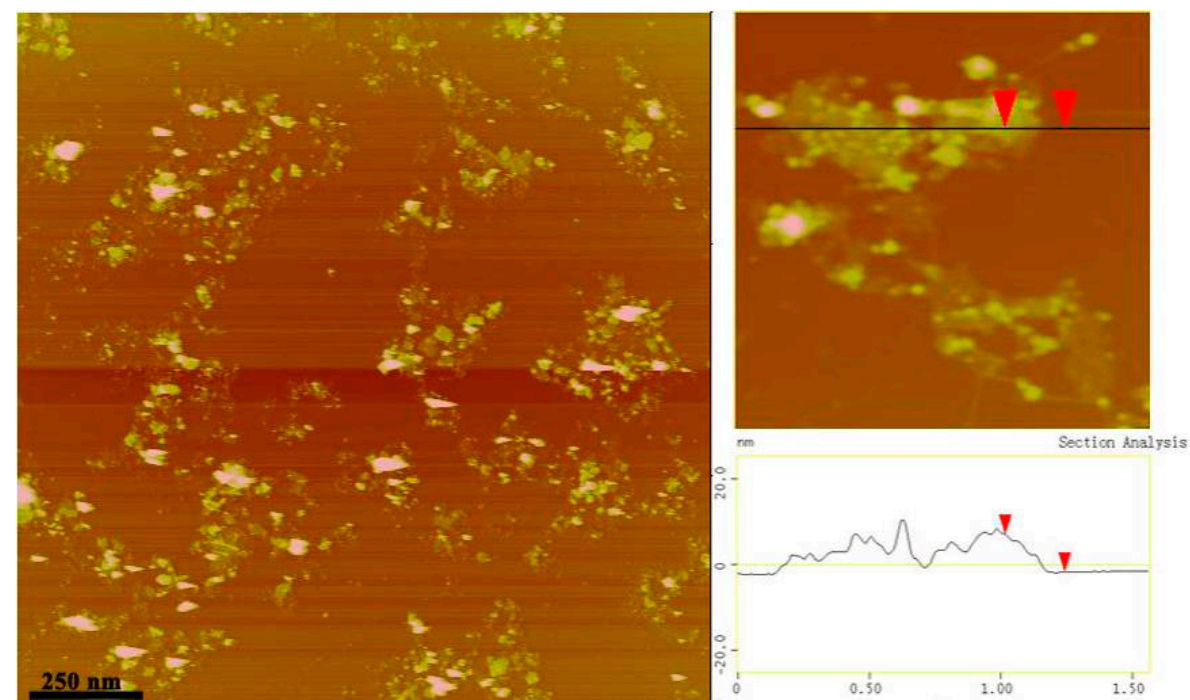

Figure 6. Atomic force microscopy (AFM) images of GO-TRIS-PEEP.

\subsection{Thermo-Responsive Behavior of GO-TRIS-PEEP}

As it is well known, PEEP has a phase transition behavior in water and form aggregates by making the solution turbid when the temperature is above its low critical solution temperature (LCST) [32,38]. The LCST behavior of PEEP is attributed to a balance between hydrophilic and hydrophobic interactions and the resulting hydrogen-bonding interactions between water molecules and the polymeric chains. It is one of the basic physical properties of thermo-responsive water-soluble polymers [52]. As expected, this thermal behavior in aqueous solution was well retained after PEEP was covalently bound to GO sheets (see the inset in Figure 7). In a typical experiment, we found that GO-TRIS-PEEP with a concentration of $0.5 \mathrm{mg} / \mathrm{mL}$ at $25^{\circ} \mathrm{C}$ formed a stable homogeneous solution. If not heated, the homogeneous solution could last more than one month. When the solution was heated to $40{ }^{\circ} \mathrm{C}$, GO-TRIS-PEEP began to aggregate. Further raising the temperature, GO-TRIS-PEEP would precipitate completely from the solution in a few minutes. When the mixture was cooled down to $25^{\circ} \mathrm{C}$, and then mildly shaken for several minutes, a homogeneous solution recovered again. This precipitation phenomenon was not observed for $\mathrm{GO}$ aqueous dispersion even if the temperature rose to $90^{\circ} \mathrm{C}$ (Figure S8), which demonstrated that PEEP segments on the surface of GO-TRIS-PEEP take account for the above- mentioned thermal responsibility. The hydrophilic/hydrophobic phase transition of PEEP-grafted GO sheets should show exothermic or endothermic effects. The change of enthalpy during phase transition can be measured by DSC. The DSC curve (Figure 7) exhibits a small endothermic peak at $\sim 74^{\circ} \mathrm{C}$, which indicates a phase transition process. Considering that GO-TRIS-PEEP nanocomposite begins to aggregate at $40{ }^{\circ} \mathrm{C}$, the phase transition process should be gradual in a wide temperature range. It might be because the abundant oxygen-containing functionalities on the surface increased the hydrophilicity of GO-TRIS-PEEP. Therefore, it is not appropriate to provide a certain temperature as the LCST. 


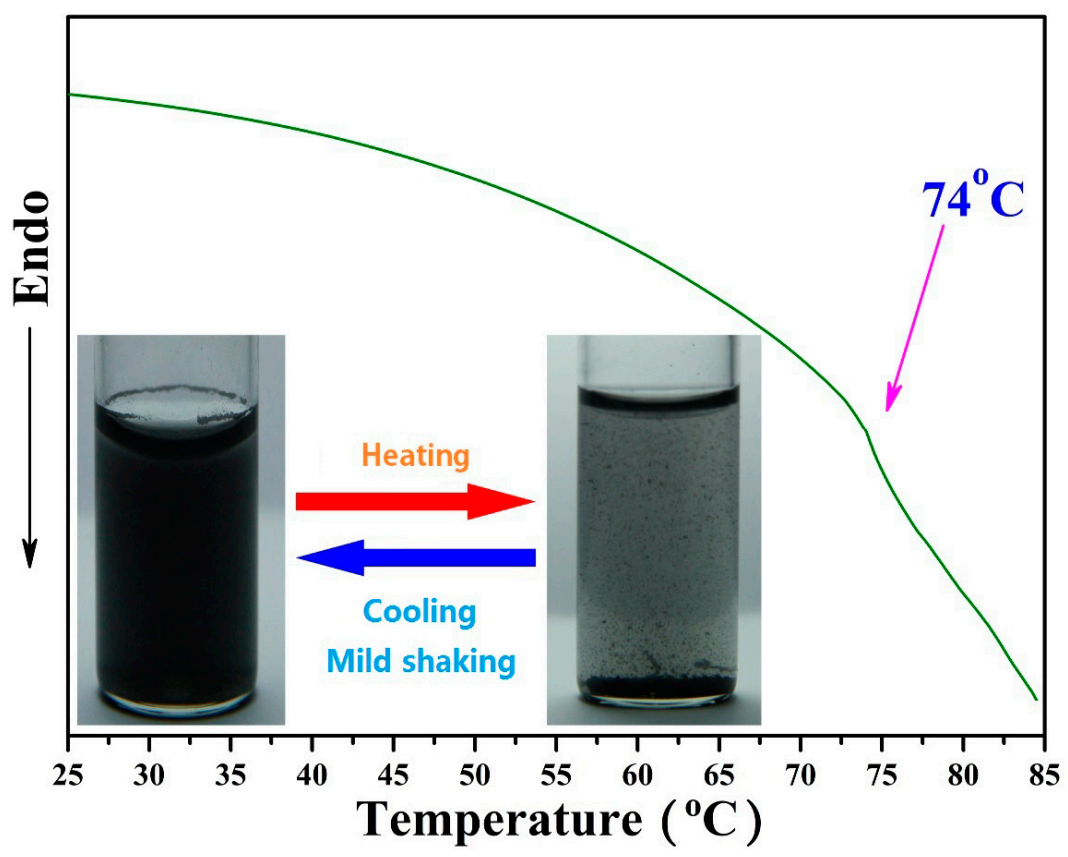

Figure 7. DSC curve of GO-TRIS-PEEP with a heating rate of $10^{\circ} \mathrm{C} / \mathrm{min}$ in $\mathrm{N}_{2}$, the inset shows the thermo-stimuli reversible phase behavior of GO-TRIS-PEEP.

\section{Conclusions}

In summary, we have successfully modified GO with the thermo-responsive PEEP chains via the grafting-from approach. To the best knowledge, this is the first example of PPE-Based $\mathrm{GO} /$ polymer nanocomposite via covalent modification. The structure of the resulting GO-TRIS-PEEP nanocomposite was well studied by various characterizations to prove the change on functionalization. Moreover, GO-TRIS-PEEP nanocomposite shows good temperature responsive behavior as a result of a conformation change in PEEP chains grafted on the surface of GO. Our work provides a potent strategy for the design and synthesis of novel GO/stimuli- responsive polymer nanocomposites, which exhibit great application potential in biological and medical as well as interdisciplinary fields.

Supplementary Materials: The following are available online at http:/ /www.mdpi.com/2079-4991/9/2/207/s1, Figure S1: FT-IR spectra of natural graphite powder and graphene oxide, Figure S2: X-ray diffraction patterns of natural graphite powder and graphene oxide, Table S1: Elementary analysis of natural graphite and graphene oxide, Figure S3: Survey XPS data for graphene oxide, the inset curve indicates that there is no N1s peak in XPS of graphene oxide, Figure S4: TGA (black) and DTG (blue) curves of graphene oxide, Figure S5: TEM images of graphene oxide with different scale bars in length, (A) $1 \mu \mathrm{m}$ and (B) $200 \mathrm{~nm}$, Figure S6: AFM images of graphene oxide, Figure S7: AFM images of graphene oxide, Figure S8: Photographs of graphene oxide aqueous solutions in different temperature with a concentration of $\sim 0.5 \mathrm{mg} / \mathrm{mL}$.

Author Contributions: Conceptualization, X.J.; methodology, X.J.; software, G.L.; validation, Y.L., F.C. and H.C.; formal analysis, X.J.; investigation, X.J.; resources, X.H. and W.L.; data curation, X.J.; writing-original draft preparation, X.J.; writing—review and editing, X.J.; visualization, X.J.; supervision, X.H. and W.L.; project administration, X.H. and W.L.; funding acquisition, X.H. and W.L.

Funding: The authors thank the financial supports from National Key Research \& Development Program of China (213 project), National Natural Science Foundation of China (21704110, 21674124 and 51773222), Strategic Priority Research Program of Chinese Academy of Sciences (XDB20000000), Shanghai Scientific and Technological Innovation Project (16DZ1205600, 16JC1402500, 16520710300, 17DZ1205400 and 18ZR1449900), Opening Project of Shanghai Key Laboratory of Crime Scene Evidence (2015XCWZK02, 2017XCWZK24 and 2015XCWZK15) and Science and Technology Development Fund of Shanghai Municipal Public Security Bureau (2018002 and 2018003).

Conflicts of Interest: The authors declare no conflict of interest. 


\section{References}

1. Dikin, D.A.; Stankovich, S.; Zimney, E.J.; Piner, R.D.; Dommett, G.H.B.; Evmenenko, G.; Nguyen, S.T.; Ruoff, R.S. Preparation and characterization of graphene oxide paper. Nature 2007, 448, 457-460. [CrossRef] [PubMed]

2. Becerril, H.A.; Mao, J.; Liu, Z.; Stoltenberg, R.M.; Bao, Z.; Chen, Y. Evaluation of solution-processed reduced graphene oxide films as transparent conductors. ACS Nano 2008, 2, 463-470. [CrossRef]

3. Georgakilas, V.; Tiwari, J.N.; Kemp, K.C.; Perman, J.A.; Bourlinos, A.B.; Kim, K.S.; Zboril, R. Noncovalent functionalization of graphene and graphene oxide for energy materials, biosensing, catalytic, and biomedical applications. Chem. Rev. 2016, 116, 5464-5519. [CrossRef] [PubMed]

4. Marcano, D.C.; Kosynkin, D.V.; Berlin, J.M.; Sinitskii, A.; Sun, Z.; Slesarev, A.; Alemany, L.B.; Lu, W.; Tour, J.M. Improved synthesis of graphene oxide. ACS Nano 2010, 4, 4806-4814. [CrossRef] [PubMed]

5. Dreyer, D.R.; Park, S.; Bielawski, C.W.; Ruoff, R.S. The chemistry of graphene oxide. Chem. Soc. Rev. 2010, 39, 228-240. [CrossRef] [PubMed]

6. Zhu, Y.W.; Murali, S.; Cai, W.; Li, X.; Suk, J.W.; Potts, J.R.; Ruoff, R.S. Graphene and graphene oxide: synthesis, properties, and applications. Adv. Mater. 2010, 22, 3906-3924. [CrossRef] [PubMed]

7. Narayanan, T.N.; Gupta, B.K.; Vithayathil, S.A.; Aburto, R.R.; Mani, S.A.; Tijerina, J.T.; Xie, B.; Kaipparettu, B.A.; Torti, S.V.; Ajayan, P.M. Hybrid 2D nanomaterials as dual-mode contrast agents in cellular imaging. Adv. Mater. 2012, 24, 2992-2998. [CrossRef]

8. Robinson, J.T.; Tabakman, S.M.; Liang, Y.; Wang, H.; Casalongue, H.S.; Vinh, D.; Dai, H.J. Ultrasmall reduced graphene oxide with high near-infrared absorbance for photothermal therapy. J. Am. Chem. Soc. 2011, 133, 6825-6831. [CrossRef]

9. Guan, F.L.; An, F.; Yang, J.; Li, X.; Li, X.H.; Yu, Z.Z. Fiber reinforced three-dimensional graphene aerogels for electrically conductive epoxy composites with enhanced mechanical properties. Chin. J. Polym. Sci. 2017, 35, 1381-1390. [CrossRef]

10. Liu, Z.; Robinson, J.T.; Sun, X.; Dai, H.J. PEGylated nano-graphene oxide for delivery of water insoluble cancer drugs. J. Am. Chem. Soc. 2008, 130, 10876-10877. [CrossRef]

11. Zhang, X.; Yin, J.; Peng, C.; Hu, W.; Zhu, Z.; Li, W.; Fan, C.H.; Huang, Q. Distribution and biocompatibility studies of graphene oxide in mice after intravenous administration. Carbon 2011, 49, 986-995. [CrossRef]

12. Bitounis, D.; Ali-Boucetta, H.; Hong, B.H.; Min, D.H.; Kostarelos, K. Prospects and challenges of graphene in biomedical applications. Adv. Mater. 2013, 25, 2258-2268. [CrossRef] [PubMed]

13. Liu, J.; Cui, L.; Losic, D. Graphene and graphene oxide as new nanocarriers for drug delivery applications. Acta Biomater. 2013, 9, 9243-9257. [CrossRef] [PubMed]

14. Loh, K.P.; Bao, Q.; Ang, P.K.; Yang, J. The chemistry of graphene. J. Mater. Chem. 2010, 20, 2277-2289. [CrossRef]

15. Chen, Y.; Li, D.X.; Yang, W.Y.; Xiao, C.G.; Wei, M.L. Effects of different amine-functionalized graphene on the mechanical, thermal, and tribological properties of polyimide nanocomposites synthesized by in situ polymerization. Polymer 2018, 140, 56-72. [CrossRef]

16. Nia, A.S.; Binder, W.H. Graphene as initiator/catalyst in polymerization chemistry. Prog. Polym. Sci. 2017, $67,48-76$.

17. Kuila, T.; Bose, S.; Mishra, A.K.; Khanra, P.; Kim, N.H.; Lee, J.H. Chemical functionalization of graphene and its applications. Prog. Mater. Sci. 2012, 57, 1061-1105. [CrossRef]

18. Goncalves, G.; Marques, P.A.A.P.; Granadeiro, C.M.; Nogueira, H.I.S.; Singh, M.K.; Gracio, J. Surface modification of graphene nanosheets with gold nanoparticles: The role of oxygen moieties at graphene surface on gold nucleation and growth. Chem. Mater. 2009, 21, 4796-4802. [CrossRef]

19. Luan, Y.G.; Zhang, X.A.; Jiang, S.L.; Chen, J.H.; Lyu, Y.F. Self-healing supramolecular polymer composites by hydrogen bonding interactions between hyperbranched polymer and graphene oxide. Chin. J. Polym. Sci. 2018, 36, 584-591. [CrossRef]

20. Wang, N.; Tian, H.; Zhu, S.Y.; Yan, D.Y.; Mai, Y.Y. Two-dimensional nitrogen-doped mesoporous carbon/graphene nanocomposites from the self-assembly of block copolymer micelles in solution. Chin. J. Polym. Sci. 2018, 36, 266-272. [CrossRef]

21. Balcioglu, M.; Buyukbekar, B.Z.; Yavuz, M.S.; Yigit, M.V. Smart-polymer-functionalized graphene nanodevices for thermo-switch-controlled biodetection. ACS Biomater. Sci. Eng. 2015, 1, 27-36. [CrossRef] 
22. Pan, Y.Z.; Bao, H.Q.; Sahoo, N.G.; Wu, T.F.; Li, L. Water-soluble poly (N-isopropylacrylamide)-graphene sheets synthesized via click chemistry for drug delivery. Adv. Funct. Mater. 2011, 21, 2754-2763. [CrossRef]

23. Peng, X.; Liu, T.Q.; Shang, C.; Jiao, C.; Wang, H.L. Mechanically strong Janus poly( $N$-isopropylacrylamide)/graphene oxide hydrogels as thermo-responsive soft robots. Chin. J. Polym. Sci. 2017, 35, 1268-1275. [CrossRef]

24. Sun, S.; Wu, P. A One-Step Strategy for Thermal- and $\mathrm{pH}$-responsive graphene oxide interpenetrating polymer hydrogel networks. J. Mater. Chem. 2011, 21, 4095-4097. [CrossRef]

25. Yang, Y.; Wang, J.; Zhang, J.; Liu, J.; Yang, X.; Zhao, H. Exfoliated graphite oxide decorated by PDMAEMA chains and polymer particles. Langmuir 2009, 25, 11808-11814. [CrossRef] [PubMed]

26. Wang, D.R.; Wang, X.G. Self-assembled graphene/azo polyelectrolyte multilayer film and its application in electrochemical energy storage device. Langmuir 2011, 27, 2007-2013. [CrossRef]

27. Tran, T.H.; Nguyen, H.T.; Pham, T.T.; Choi, J.Y.; Choi, H.G.; Yong, C.S.; Kim, J.O. Development of a graphene oxide nanocarrier for dual-drug chemo-phototherapy to overcome drug resistance in cancer. ACS Appl. Mater. Interfaces 2015, 7, 28647-28655. [CrossRef]

28. Jiang, X.; Deng, Y.; Liu, W.B.; Li, Y.J.; Huang, X.Y. Preparation of graphene/poly(2-acryloxyethyl ferrocenecarboxylate) nanocomposite via a "grafting-onto" strategy. Polym. Chem. 2018, 9, 184-192. [CrossRef]

29. Wang, Y.C.; Liu, X.C.; Sun, T.M.; Xiong, M.H.; Wang, J. Functionalized micelles from block copolymer of polyphosphoester and poly( $\varepsilon$-caprolactone) for receptor-mediated drug delivery. J. Control. Release 2008, 128, 32-40. [CrossRef]

30. Appukutti, N.; Serpell, C.J. High definition polyphosphoesters: between nucleic acids and plastics. Polym. Chem. 2018, 9, 2210-2226. [CrossRef]

31. Yuan, Y.Y.; Du, Q.; Wang, Y.C.; Wang, J. One-pot syntheses of amphiphilic centipede-like brush copolymers via combination of ring-opening polymerization and "click" chemistry. Macromolecules 2010, 43, 1739-1746. [CrossRef]

32. Iwasaki, Y.; Wachiralarpphaithoon, C.; Akiyoshi, K. Novel Thermoresponsive polymers having biodegradable phosphoester backbones. Macromolecules 2007, 40, 8136-8138. [CrossRef]

33. Liu, J.Y.; Huang, W.; Pang, Y.; Yan, D.Y. Hyperbranched polyphosphates: synthesis, functionalization and biomedical applications. Chem. Soc. Rev. 2015, 44, 3942-3952. [CrossRef] [PubMed]

34. Du, X.; Sun, Y.; Zhang, M.; He, J.L.; Ni, P.H. Polyphosphoester-camptothecin prodrug with reduction-response prepared via Michael addition polymerization and click reaction. ACS Appl. Mater. Interfaces 2017, 9, 13939-13949. [CrossRef] [PubMed]

35. Hindi, K.M.; Ditto, A.J.; Panzner, M.J.; Medvetz, D.A.; Han, D.S.; Hovis, C.E.; Hilliard, J.K.; Taylor, J.B.; Yun, Y.H.; Cannon, C.L.; et al. The antimicrobial efficacy of sustained release silver-carbine complex-loaded L-tyrosine polyphosphate nanoparticles: characterization, in vitro and in vivo Studies. Biomaterials 2009, 30, 3771-3779. [CrossRef] [PubMed]

36. Zhao, Z.; Wang, J.; Mao, H.Q.; Leong, K.W. Polyphosphoesters in drug and gene delivery. Adv. Drug Deliv. Rev. 2003, 55, 483-499. [CrossRef]

37. Gu, Z.; Xie, H.; Li, L.; Zhang, X.; Liu, F.; Yu, X. Application of strontium-doped calcium polyphosphate scaffold on angiogenesis for bone tissue engineering. J. Mater. Sci. Mater. Med. 2013, 24, 1251-1260. [CrossRef] [PubMed]

38. Wang, Y.C.; Tang, L.Y.; Li, Y.; Wang, J. Thermoresponsive block copolymers of poly (ethylene glycol) and polyphosphoester: thermo-induced self-assembly, biocompatibility, and hydrolytic degradation. Biomacromolecules 2009, 10, 66-73. [CrossRef]

39. Kricheldorf, H.R.; Kreiser-Saunders, I.; Stricker, A. Polylactones 48. SnOct 2 -initiated polymerizations of lactide: A mechanistic study. Macromolecules 2000, 33, 702-709. [CrossRef]

40. Shen, J.F.; Hu, Y.Z.; Shi, M.; Li, N.; Ma, H.W.; Ye, M.X. One step synthesis of graphene oxide-magnetic nanoparticle composite. J. Phys. Chem. C 2010, 114, 1498-1503. [CrossRef]

41. Bui, T.N.H.; Verhage, J.J.; Irgum, K. Tris(hydroxymethyl)aminomethane-functionalized silica particles and their application for hydrophilic interaction chromatography. J. Sep. Sci. 2010, 33, 2965-2976. [CrossRef] [PubMed]

42. Mallakpour, S.; Abdolmaleki, A.; Khalesi, Z.; Borandeh, S. Surface functionalization of GO, preparation and characterization of PVA/TRIS-GO nanocomposites. Polymer 2015, 81, 140-150. [CrossRef] 
43. Yang, H.F.; Shan, C.S.; Li, F.H.; Han, D.X.; Zhang, Q.X.; Niu, L. Covalent functionalization of polydisperse chemically-converted graphene sheets with amine-terminated ionic liquid. Chem. Commun. 2009, 3880-3882. [CrossRef] [PubMed]

44. Ryner, M.; Stridsberg, K.; Albertsson, A.C. Mechanism of ring-opening polymerization of 1,5-dioxepan-2-oneandL-lactide with stannous 2-ethylhexanoate. A theoretical study. Macromolecules 2001, 34, 3877-3881. [CrossRef]

45. Nakajima, T.; Mabuchi, A.; Hagiwara, R. A new structure model of graphite oxide. Carbon 1988, 26, 357-361. [CrossRef]

46. Teng, C.Y.; Yeh, T.F.; Lin, K.I.; Chen, S.J.; Yoshimura, M.; Teng, H. Synthesis of graphene oxide dots for excitation-wavelength independent photoluminescence at high quantum yields. J. Mater. Chem. C 2015, 3, 4553-4562. [CrossRef]

47. Deng, Y.; Zhang, J.Z.; Li, Y.J.; Hu, J.H.; Yang, D.; Huang, X.Y. Thermoresponsive graphene oxide-PNIPAM nanocomposites with controllable grafting polymer chains via moderate in situ SET-LRP. J. Polym. Sci. Polym. Chem. 2012, 50, 4451-4458. [CrossRef]

48. Deng, Y.; Li, Y.J.; Dai, J.; Lang, M.D.; Huang, X.Y. Functionalization of graphene oxide towards thermo-sensitive nanocomposites via moderate in situ SET-LRP. J. Polym. Sci. Polym. Chem. 2011, 49, 4747-4755. [CrossRef]

49. Fang, M.; Wang, K.G.; Lu, H.B.; Yang, Y.L.; Nutt, S. Covalent polymer functionalization of graphene nanosheets and mechanical properties of composites. J. Mater. Chem. 2009, 19, 7098-7105. [CrossRef]

50. Xu, Z.; Gao, C. In situ Polymerization approach to graphene-reinforced nylon-6 composites. Macromolecules 2010, 43, 6716-6723. [CrossRef]

51. Fang, M.; Wang, K.G.; Lu, H.B.; Yang, Y.L.; Nutt, S. Single-layer graphene nanosheets with controlled grafting of polymer chains. J. Mater. Chem. 2010, 20, 1982-1992. [CrossRef]

52. Sánchez-Moreno, P.; Vicente, J.D.; Nardecchia, S.; Marchal, J.A.; Boulaiz, H. Thermo-sensitive nanomaterials: recent advance in synthesis and biomedical applications. Nanomaterials 2018, 8, 935. [CrossRef] [PubMed]

(C) 2019 by the authors. Licensee MDPI, Basel, Switzerland. This article is an open access article distributed under the terms and conditions of the Creative Commons Attribution (CC BY) license (http:/ / creativecommons.org/licenses/by/4.0/). 